\title{
Weathering Behaviour of Cunninghamia lanceolata (Lamb.) Hook. under Natural Conditions
}

\author{
Xinjie Cui ${ }^{1}$ (I) and Junji Matsumura ${ }^{2, *}$ \\ 1 Graduate School of Bioresource and Bioenvironmental Sciences, Faculty of Agriculture, Kyushu University, \\ 744 Motooka, Nishi-ku, Fukuoka 819-0395, Japan; Cuixinjie0731@outlook.com \\ 2 Laboratory of Wood Science, Faculty of Agriculture, Kyushu University, 744 Motooka, Nishi-ku, \\ Fukuoka 819-0395, Japan \\ * Correspondence: matumura@agr.kyushu-u.ac.jp; Tel.: +81-092-802-4656
}

Received: 18 July 2020; Accepted: 10 December 2020; Published: 14 December 2020

check for updates

\begin{abstract}
Information on the weathering behaviour of Cunninghamia lanceolata (Lamb.) Hook. is needed to provide references for wood weatherproof pre-treatment and to improve wood utilization. Therefore, this study was conducted to understand the variation in the intrinsic weathering behaviour of Cunninghamia lanceolata (Chinese fir) under natural conditions. Wood samples from 15 Cunninghamia lanceolata trees aged 26-30 years old were used. The structural degradation and discoloration of wood surfaces before and after exposure were compared. The results show that the weathering behaviour of wood was weakened from heartwood to sapwood and enhanced from the bottom to the top. This study provided information for weatherability research and improved wood utilization of Cunninghamia lanceolata.
\end{abstract}

Keywords: Cunninghamia lanceolata; weathering; density; colour change; wood structure

\section{Introduction}

Cunninghamia lanceolata (Lamb.) Hook. is a member of the family Cupressaceae. It is an evergreen tree that can grow up to $50 \mathrm{~m}$ in height and over $3 \mathrm{~m}$ in diameter. It forms mixed broad-leaved forests or small, pure stands, rocky hillsides, roadsides, with altitudes ranging from 200 to $2800 \mathrm{~m}$ [1]. It grows naturally in China, Laos, Vietnam, Malaysia, and Cambodia. Plantations have been established in countries including Argentina, Japan, New Zealand, South Africa. It adapts to the climatic conditions with an annual average temperature of $16-19^{\circ} \mathrm{C}$, extreme minimum temperature of $-15^{\circ} \mathrm{C}$, and annual precipitation of $900-2350 \mathrm{~mm}$. Its advantages are excellent material properties, attractive scent, moderate hardness, straight texture, and easy processing. In China, Cunninghamia lanceolata accounts for $20 \%-30 \%$ of the total commercial timber production [2-4]. In recent years, about 400,000 ha. of plantations have been established annually by seedlings and cuttings in Southeastern China [5].

Cunninghamia lanceolata (Chinese fir) has a fragrant smell and contains cedar camphor [6]. After the decay test using Postia placenta and Trametes versicolor, Chinese fir was classified as a slightly durable wood. It showed moderate resistance to termites either in the laboratory or in the field [7]. It has been widely used for constructing buildings, bridges, ships, and lamp posts in furniture manufacturing and for producing wood fibre $[1,3,4]$. Therefore, Chinese fir is extensively used in outdoor environments. For example, it has been used as the main building material of Chinese Dong minority drum towers and wind and rain bridges [8,9]. Despite the multiple studies on the wood properties of Chinese fir, there are still many unknowns regarding its weathering. Studying the weathering behaviour is important because it can aid in determining the most effective treatment methods and guide the establishment and refinement of Chinese fir weathering protection methods. 
Differences in weathering behaviour exist among various species [10-16]. According to the variation in the wood properties of different positions within the same tree species [17-21], it is inferred that there are also differences in degradation characteristics inside the wood. The study of natural weathering usually involves a long-term research study. Problems such as missing samples during experiments would affect the accuracy of experimental results. However, differences in artificial weathering test results occurred in previous research studies, and these tests cannot completely replace natural weathering $[22,23]$. In the current study, the effects of weathering on wood began with the exposure of samples to natural conditions [24,25]. Effects of weathering on wood could be obtained in a short period by focusing on the changes in the wood surface. The purpose of this study is to clarify the variation in intrinsic weathering behaviour of Cunninghamia lanceolata. We completed a short outdoor exposure experiment and observed the aging differences within trees of Cunninghamia lanceolata along the radial and axial directions. To attain these objectives, colour and anatomical structure were used to compare and analyse changes in the surface of the wood. This study obtained information on degradation characteristics, which provided references for the study on the weatherability of Cunninghamia lanceolata.

\section{Materials and Methods}

\subsection{Wood Sample Preparation}

Fifteen trees aged 26-30 years and without any major defects were selected. Each tree sample was cut from a $2.5 \mathrm{~cm}$ thick $\log$ at $1,2,3$, and $4 \mathrm{~m}$ above the ground. The surfaces of the samples were smoothed by sanding with abrasive paper. As shown in Figure 1, for the selected samples, the grain was required to be straight, and there were no nodes or visible defects.

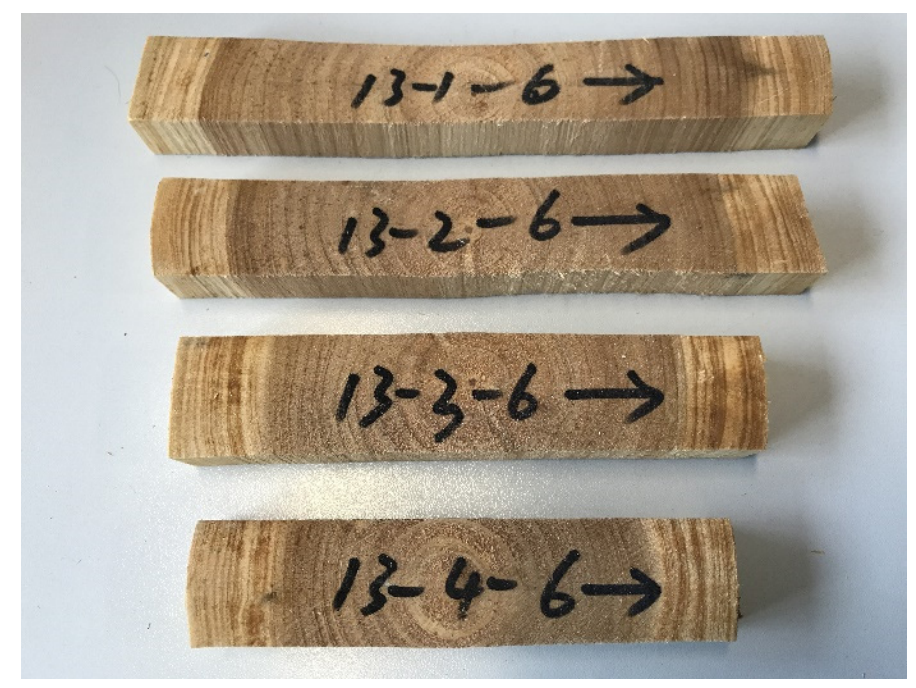

Figure 1. Samples were cut through the pith from Cunninghamia lanceolata (Lamb.) Hook. (at 1, 2, 3, $4 \mathrm{~m}$ heights).

\subsection{Density}

As shown in Figure 2, due to the different growth rings, at 1, 2, 3, and $4 \mathrm{~m}$ from the ground, a sample of each of three growth ring position was cut to measure the density of the wood. The total sample number of this experiment was 540 . 


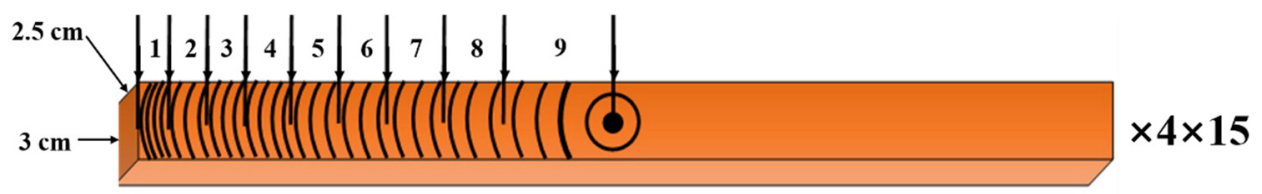

Figure 2. Samples for wood-specific gravity testing.

Wood density measurement samples were placed in a conditioning room at $20{ }^{\circ} \mathrm{C}$ and $65 \%$ relative humidity. The moisture content of wood was maintained at 10-12\%. The instrument used to measure density was an electronic densimeter (MD-300S, Alfa Mirage, Tokyo, Japan) [26]. The device adopted Archimedes' principle and the determination of the value of relative density was based on a $1 \mathrm{~g} / \mathrm{cm}^{3}$ water density at $4{ }^{\circ} \mathrm{C}$. As shown in Figure 3, the measurement procedure was as follows. Firstly, the sample was weighed. Secondly, it was placed in water. Finally, the density of sample was calculated to be stable [27]. In this experiment, each sample took roughly the same amount of time to enter the water, and the values quickly reached equilibrium. Therefore, the effect of the wood absorbing water was ignored. In total, 540 samples were measured by this method.

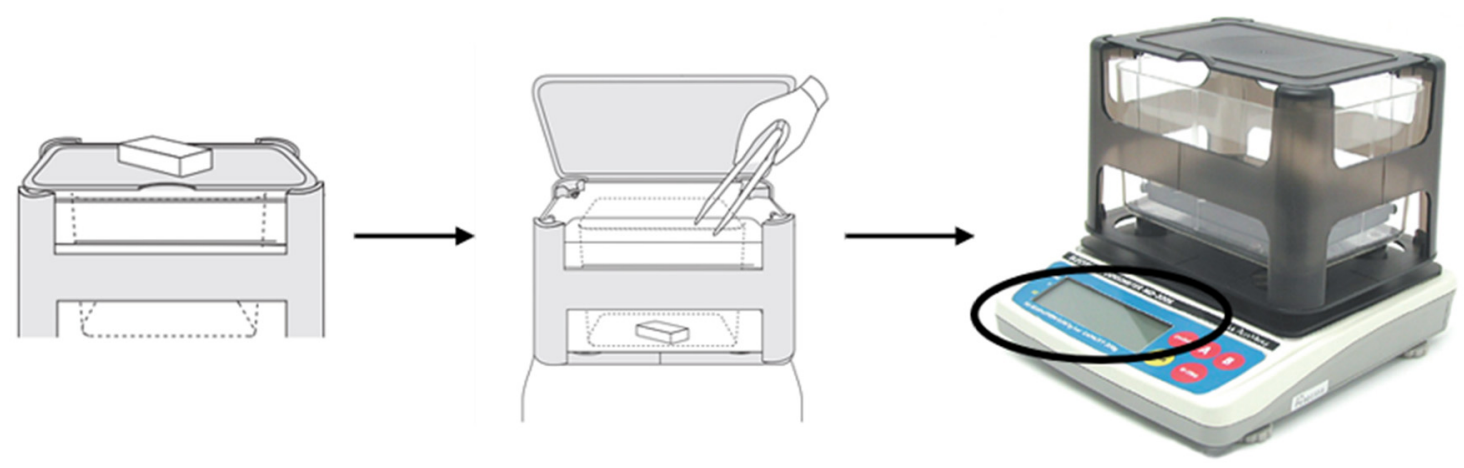

Figure 3. The procedure of the measurement of density [27].

\subsection{Weathering Conditions}

Samples were exposed to natural conditions over a period of 30 days. The samples were placed outdoors in a complete block design, facing equatorially (south), and at an angle of $45^{\circ}$ to the horizontal, in Fukuoka (latitude $33^{\circ}$ north), Japan, during the summer of 2017, as shown in Table 1 [28]. Fukuoka has a humid subtropical climate. The Scheffer index values of Fukuoka are in the range between 82 and 95 using 50 year climate data (1969 to 2019) [29,30]. At the end of 6 days of exposure, all of the specimens were retrieved from the weathering racks and measured in a laboratory, after which they were placed back on the racks. This process was repeated after 12,18, and 30 days of exposure [31]. After each exposure, all of the samples were lightly blown with nitrogen to remove dust from the exposed surfaces.

Table 1. Weathering conditions in Fukuoka during summer 2017.

\begin{tabular}{cccccc}
\hline $\begin{array}{c}\text { Weather } \\
\text { Condition }\end{array}$ & $\begin{array}{c}\text { Temperature } \\
\left.\mathbf{(}{ }^{\circ} \mathbf{C}\right)\end{array}$ & $\begin{array}{c}\text { Humidity } \\
(\mathbf{\%})\end{array}$ & $\begin{array}{c}\text { Sunshine } \\
\text { Duration }(\mathbf{h})\end{array}$ & $\begin{array}{c}\text { Total Rainfall } \\
(\mathbf{m m})\end{array}$ & $\begin{array}{c}\text { Wind Speed } \\
\mathbf{( m / s )}\end{array}$ \\
\hline Mean value $\pm \mathrm{SD}$ & $29.42 \pm 1.40$ & $74.98 \pm 6.97$ & $7.51 \pm 3.37$ & 3.90 & $2.93 \pm 0.77$ \\
\hline \multicolumn{2}{c}{ Note: the parameters show the average and standard deviation $(\mathrm{SD})$ during July and August $2017(\mathrm{~N}=30)}$.
\end{tabular}

\subsection{Low-Vacuum Scanning Electron Microscopy}

As shown in Figure 4, the heartwood and sapwood samples were cut into $10(\mathrm{R}) \times 10(\mathrm{~T}) \times 10(\mathrm{~L})$ $\mathrm{mm}$ small wood samples at axial heights of 1-4 $\mathrm{m}$. This size sample was obtained for 120 blocks. 
Microstructure observation samples were cut using a sledge microtome to reveal three sections at different samples, and the cut samples were placed in a $60^{\circ} \mathrm{C}$ dry environment.
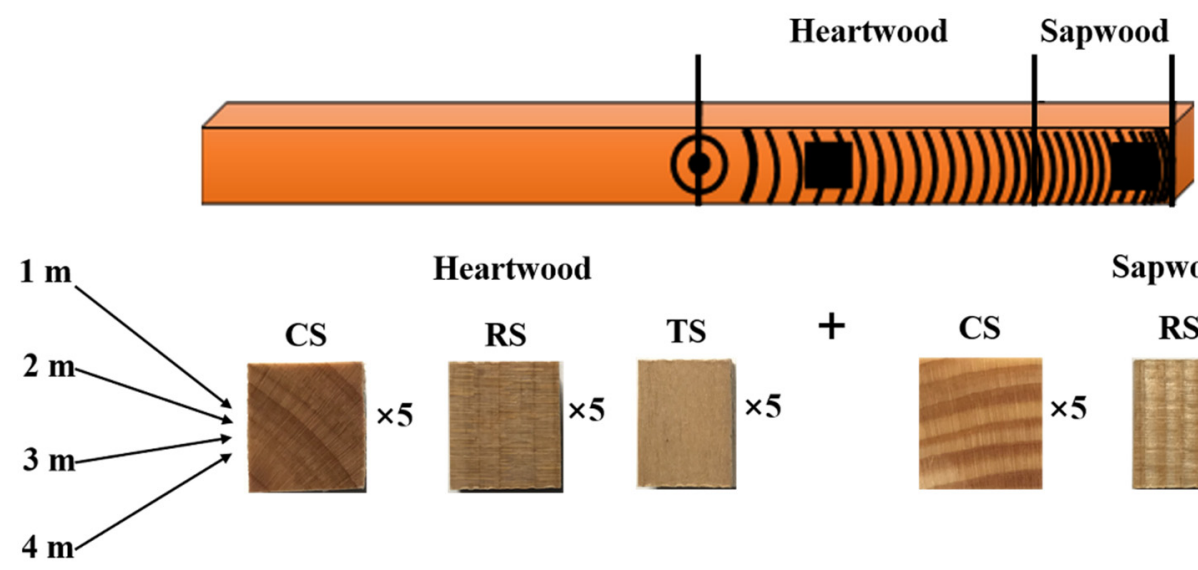

Heartwood

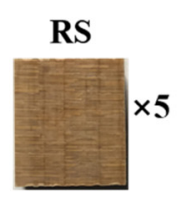

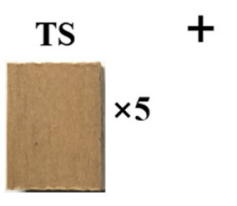

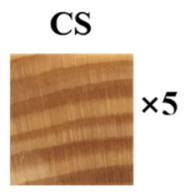

Sapwood

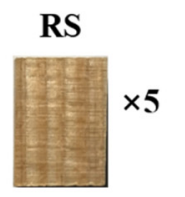

TS

Figure 4. Microstructure observation samples were cut into $10(\mathrm{R}) \times 10(\mathrm{~T}) \times 10(\mathrm{~L}) \mathrm{mm}$.

Uncoated samples were observed by low-vacuum scanning electron microscopy (LVSEM, JEOL JSM-5600LV, JEOL, Tokyo, Japan) before and after natural exposure. The conditions were as follows: voltage $15 \mathrm{kV}$; pressure 10-30 Pa; and working distance, under 10-20 mm [32,33]. The same surface was repeatedly analysed before exposure and at the end of each alteration period.

\subsection{Colour Measurements}

Colour measurements were used to evaluate the colour change of wood surfaces before and after each period of natural exposure. The samples' size was the same as the microstructure observation samples. The colour measurements were performed on tangential sections of each sample. The preparation of 80 samples is shown in Figure 5; 30 measurements were performed per sample.

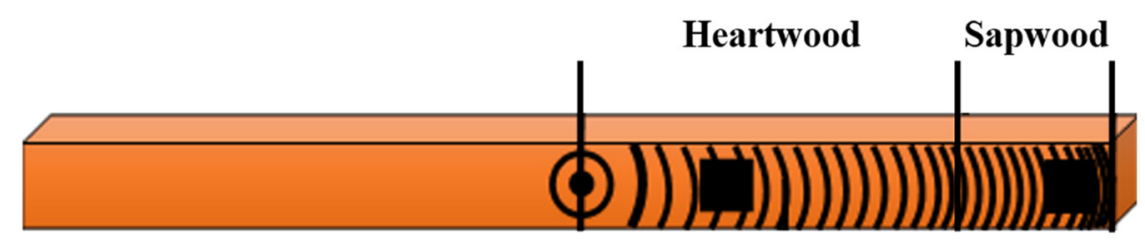

Tangential Section

Heartwood

$1 \mathrm{~m} \times 102 \mathrm{~m} \times 10 \quad 3 \mathrm{~m} \times 10 \quad 4 \mathrm{~m} \times 10 \quad 1 \mathrm{~m} \times 102 \mathrm{~m} \times 103 \mathrm{~m} \times 104 \mathrm{~m} \times 10$

Figure 5. Colour measurement samples.

A Nippon Denshoku handy colorimeter (model NR-3000, Nippon Denshoku, Tokyo, Japan) was used to measure colour with the CIE L*a*b* system [34]. This system evaluates colour based on three parameters: lightness coordinates, with $\mathrm{L}^{*}$ and $+\mathrm{L}^{*}$ for lighting and $-\mathrm{L}^{*}$ towards darkening; and the chromaticity coordinates $\mathrm{a}^{*}$ and $\mathrm{b}^{*}$, with $+\mathrm{a}^{*}$ for red, $-\mathrm{a}^{*}$ towards green, $+\mathrm{b}^{*}$ for yellow, and $-\mathrm{b}^{*}$ towards blue. The $\mathrm{L}^{*}, \mathrm{a}^{*}$, and $\mathrm{b}^{*}$ colour coordinates for each sample were determined before and after exposure to natural conditions [35]. The degree of colour change was measured on a colour measurement device by the standard illuminant D65 and standard observer $2^{\circ}$. The average values and standard deviation values were computed for each sample. These values were used to calculate colour change with the following formulas:

$$
C *=\sqrt{a^{* 2}+b^{* 2}}
$$




$$
\begin{gathered}
\Delta \mathrm{C}^{*}=\mathrm{C}^{*}-\mathrm{C}_{\mathrm{o}}{ }^{*} \\
\Delta \mathrm{E} *=\sqrt{\Delta \mathrm{L}^{* 2}+\Delta \mathrm{a}^{* 2}+\Delta \mathrm{b}^{* 2}} \\
\Delta \mathrm{H} *=\sqrt{\Delta \mathrm{E}^{* 2}-\Delta \mathrm{L}^{* 2}-\Delta \mathrm{C}^{* 2}}
\end{gathered}
$$

where $\Delta \mathrm{L}^{*}, \Delta \mathrm{a}^{*}$, and $\Delta \mathrm{b}^{*}$ are the respective changes in $\mathrm{L}^{*}, \mathrm{a}^{*}$, and $\mathrm{b}^{*}$ between the unexposed and exposed interval values. $C^{*}$ indicates chroma, while $\Delta C^{*}$ indicates the chroma difference. $\Delta \mathrm{E}^{*}$ describes the total colour-difference value and $\Delta \mathrm{H}^{*}$ denotes hue difference $[35,36]$.

\section{Results and Discussion}

\subsection{Wood Density}

Table 2 summarizes the data of wood density along the axial direction. The density of wood in the axial direction decreased from bottom to top, which agrees with the auxin gradient theory of wood [37,38]. These results agree with previous studies [39]. Ren et al. [40] indicated that the density of Cunninghamia lanceolata was $0.366-0.356 \mathrm{~g} / \mathrm{cm}^{3}$ from bottom to top.

Table 2. Variation of wood density along the stem height direction with standard errors.

\begin{tabular}{cccccc}
\hline Variable & Description & $\boldsymbol{n}$ & $\boldsymbol{\chi} \pm \mathbf{s}$ & $\mathbf{F}$ & $\boldsymbol{p}$ \\
\hline \multirow{3}{*}{ Stem height $(\mathrm{m})$} & 1 & 135 & $0.371 \pm 0.042$ & & \\
above ground & 2 & 135 & $0.362 \pm 0.044$ & & \\
& 3 & 135 & $0.358 \pm 0.039$ & 1.497 & 0.216 \\
\hline
\end{tabular}

\subsection{LVSEM Analysis}

Weathering usually refers to the slow degradation of materials when exposed to the natural environment. It can be influenced by sunlight, moisture, temperature, wind, air pollutants and other factors [22]. In fact, the wood surface changes of weathering behaviour begin from the moment the wood is exposed outdoors. According to the report, the surface characteristics of wood experience significant changes in a short exposure time [24]. Weathering of the wood surface could cause changes in colour, chemistry, physics, and anatomical structure. These changes are evident up to $0.5 \mathrm{~mm}$ below the surface during the initial period of weathering [41]. Therefore, the analysis of wood surface changes in a short period of time can also be used as a method to evaluate the weatherability of wood.

Deterioration of wood surfaces at the microscopic level during the natural weathering of the samples was observed by scanning electron microscopy (SEM). This method is a valuable tool for observing the microscopic anatomical details of degraded wood, including the cell wall shape, and evaluating changes in the cell wall. It provided deterioration information about the surfaces. The surface deterioration of the exposed wood can be observed by LVSEM. The advantage of this method is that the information is obtained intuitively and accurately [32,33]. The photodegradative effects on cross-sections and radial sections when the samples were exposed to natural weather for $30 \mathrm{~d}$ are described below (Figures 6-8). 


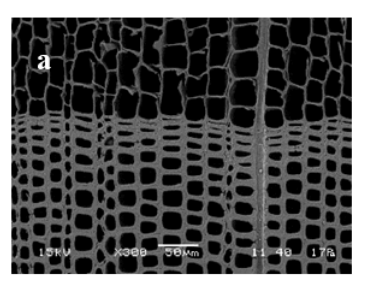

6 days
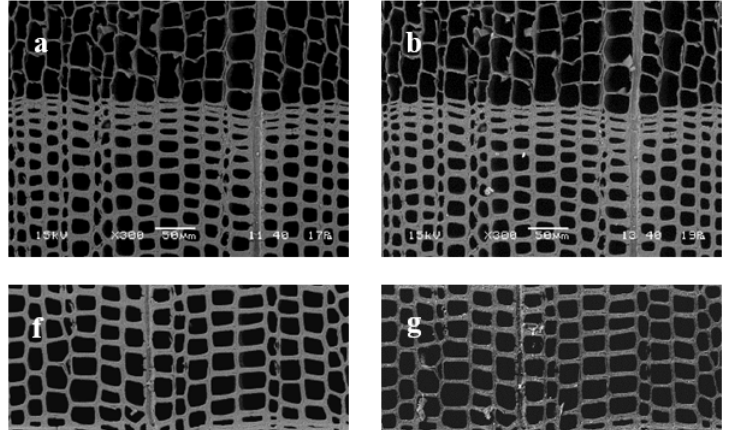

Sapwood

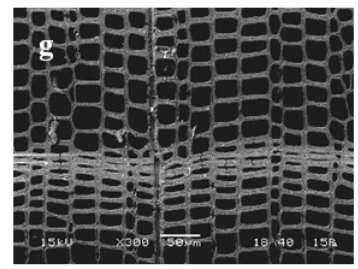

12 days
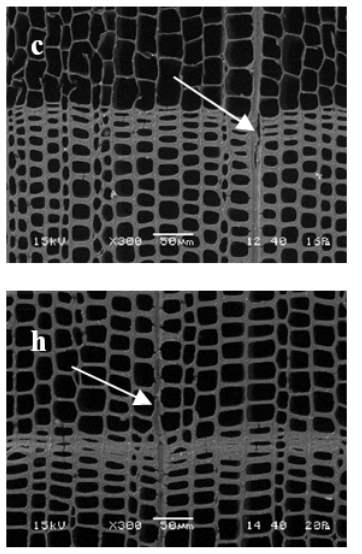

18 days
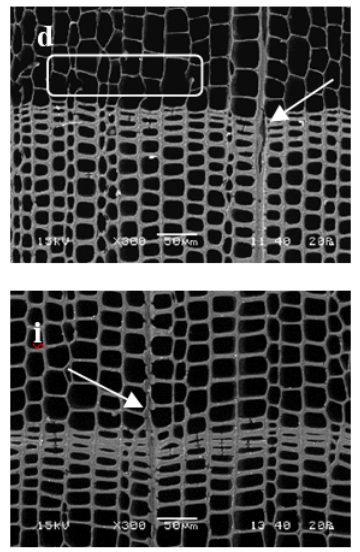

30 days
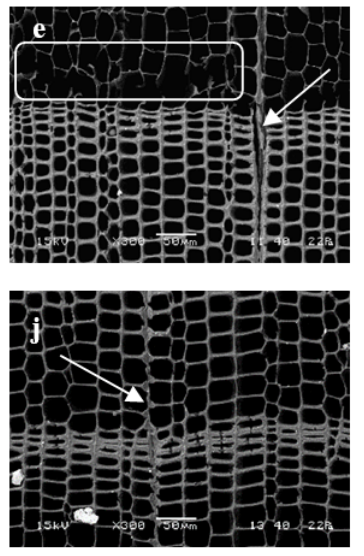

Figure 6. Low-vacuum scanning-electron-microscopy (LVSEM) micrographs $(\times 300)$ of cross-sections $(1 \mathrm{~m}$ height) of heartwood and sapwood before and after weathering. (Unexposed heartwood and sapwood surfaces were (a) and (f); (b-e), were cross-sections of heartwood after exposure 6,12,18, and 30 days; (g-j), were the surfaces of sapwood after 6,12,18, and 30 days.)

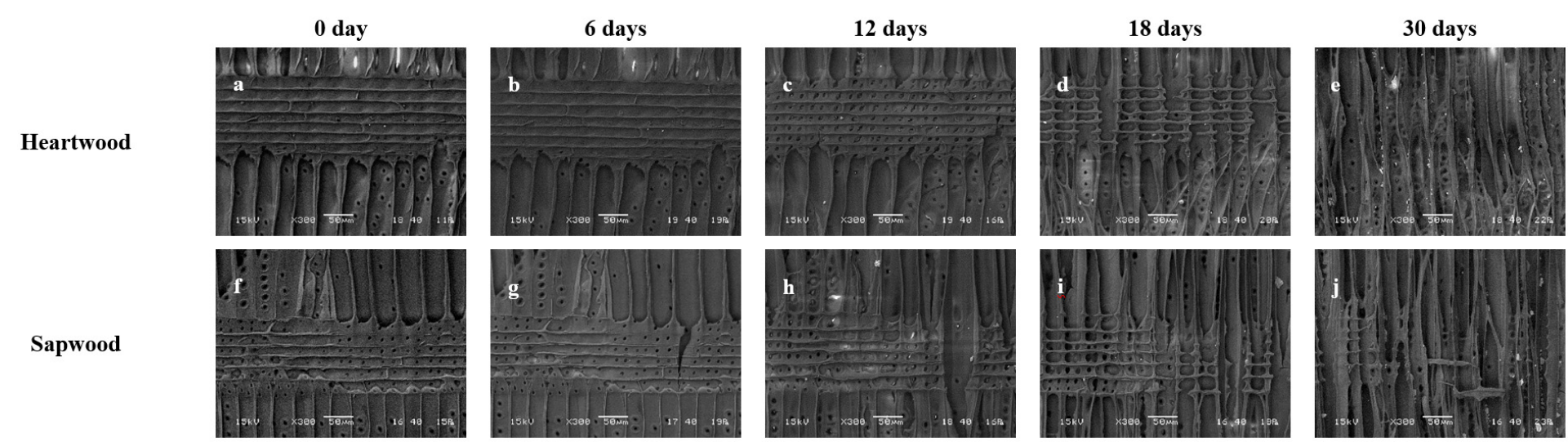

Figure 7. Low-vacuum scanning-electron-microscopy (LVSEM) micrographs ( $\times 300)$ of radial-sections (1 m height) of heartwood and sapwood before and after weathering. (Unexposed heartwood and sapwood surfaces were (a) and (f); (b-e) were radial-sections of heartwood after exposure 6,12,18, and 30 days; (g-j) were the surfaces of sapwood after 6,12,18, and 30 days.) 


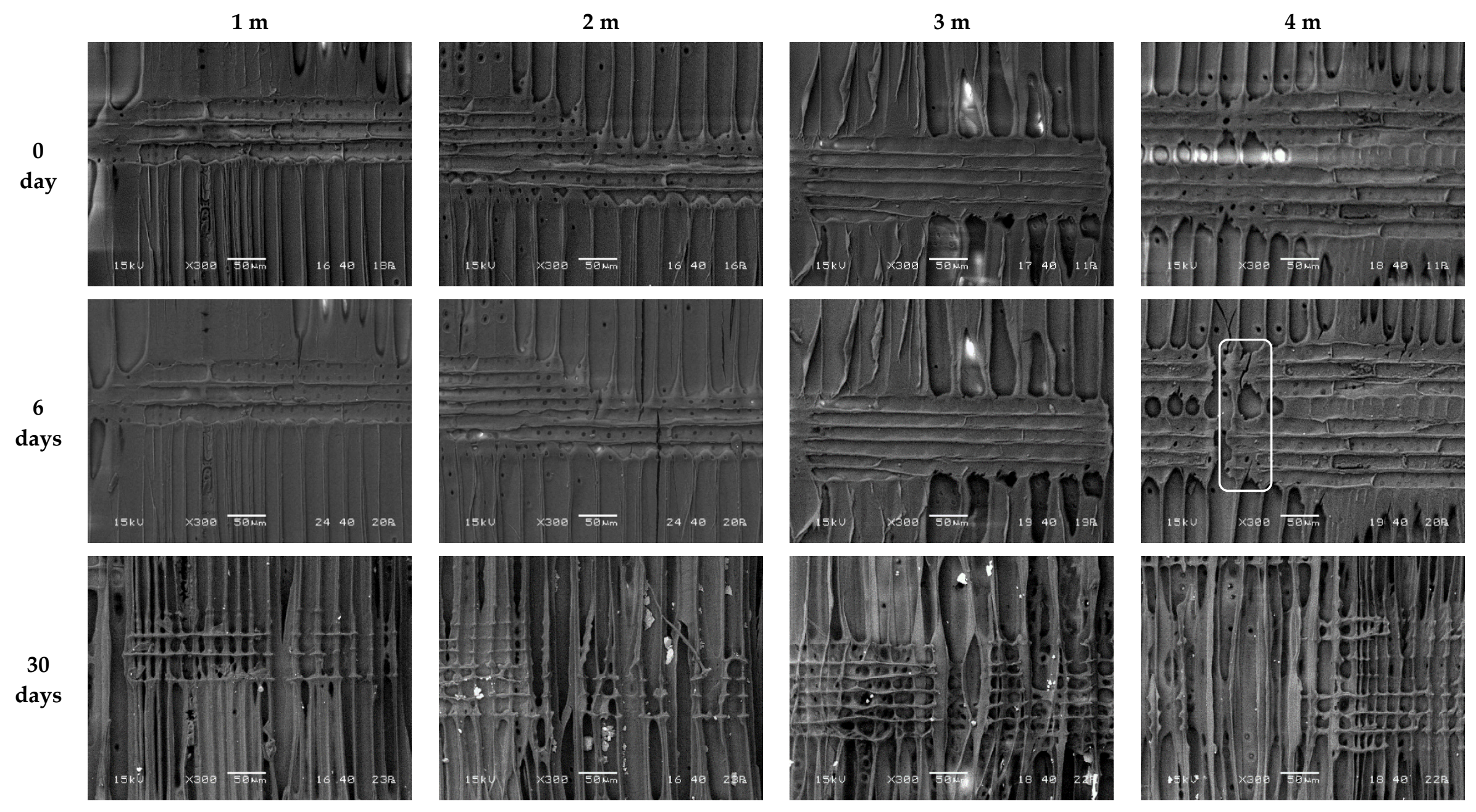

Figure 8. Low-vacuum scanning-electron-microscopy (LVSEM) micrographs $(\times 300)$ of radial-sections of different-height Chinese firs before and after weathering. 
Figure 6 shows LVSEM micrographs comparing the cross-sections of Chinese fir heartwood and sapwood before weathering (Figure 6a,f) with those after 6 days (Figure 6b,g), $12 \mathrm{~d}$ (Figure 6c,h), $18 \mathrm{~d}$ (Figure 6d,i), and $30 \mathrm{~d}$ (Figure 6e,j) of exposure. The surface of the wood exposed for $30 \mathrm{~d}$ was rougher, and four significant changes were discernible: significant loss of the middle lamella, separation of cell walls, wastage of the ray cell walls, and cell wall degradation of earlywood and latewood (as shown by the arrows in the figures). Each of these phenomena proved that further exposure resulted in more distinct changes and characteristics of the degradation process. In a previous study [42], comparable photodegradation was observed in wood that had been earlier exposed to long-wavelength UV radiation (300-400 $\mathrm{nm}$ ).

The LVSEM micrographs of radial Chinese fir surfaces are shown in Figure 7. Intact bordered pits could be observed on radial sections in both earlywood and latewood before natural weathering. The pit structures in the radial section appeared to crack after 12 days of natural weathering. The bordered pit is mainly composed of pectin and cellulose, which contain some phenolic substances [43,44]. With prolonged exposure, the phenolic substances were oxidized, and the pits cracked. Moreover, the deterioration also spread over the radial section of the tracheid walls, and roughening of cell walls was also noticed. In addition, the decrease in structural integrity was more significant in the cross-field. As seen in Figure 7d, the cross-field was entirely destroyed. After $30 \mathrm{~d}$ of exposure, the wood radial section structure was completely destroyed, especially on the heartwood surface. Compared with the cross-section, the decay of the radial section was faster and more pronounced.

Photodegradation has been found to be closely related with the change in the wood surface's chemical composition [22,45]. Based on known research, the chemical composition of softwood is distributed as follows [46]: The middle lamella and the primary wall are mainly composed of lignin $(84 \%)$, hemicellulose $(13.3 \%)$, and cellulose $(0.7 \%)$. The $\mathrm{S}_{1}$ secondary wall layer contains $51.7 \%$ lignin, 30\% cellulose, and $18.3 \%$ hemicellulose. The $\mathrm{S}_{2}$ layer is composed of $54.3 \%$ cellulose, $30.6 \%$ hemicellulose, and $15.1 \%$ lignin. The $S_{3}$ layer has $87 \%$ hemicellulose, $13 \%$ cellulose, and little or no lignin. From Figures 6 and 7, the structures of the middle lamella and primary cell wall were initially broken down during natural weathering, such as the primary cell wall of parenchyma. This is consistent with the conclusions of many academics, and lignin has always been reported as the most sensitive chemical component in wood photodegradation $[24,45,47]$. Through the observation of the cell wall degradation on the cross-section, it was found that only the skeleton structure remained after one month of natural weathering. Cellulose, hemicelluloses, and lignin are skeletal substances in wood. Cellulose, a basic skeleton material, is responsible for wood strength. Hemicellulose and lignin together are matrix systems in wood, and lignin provides wood with rigidity or stiffness. Absorption of UV light by lignin on or near the wood surface causes the preferential degradation of lignin, followed by the degradation of hemicellulose and cellulose. Cellulose is more photodegradation-resistant than hemicellulose due to its high molecular weight and protection by its crystalline structure [48-50]. The graphical result was consistent with the conclusion that the cellulose was the last to photodegrade.

The changes in the anatomical structure of heartwood and sapwood before and after weathering were compared as well. The results show various effects of weathering on heartwood and sapwood. The anti-weathering ability of the surface structure of heartwood was found to be lower than that of sapwood. Li et al. found that the heartwood cellulose content (48.6\%) of Chinese fir is lower than that of sapwood (52.0\%) on average [51]. Therefore, the photodegradation of heartwood after 30 days was more serious, as shown in Figures 6 and 7.

The LVSEM micrographs in Figure 8 show that during the weathering process the surface structure of Chinese fir changed in different heights. After weathering for one week, the surface structure of Chinese fir began to degrade; the change at the $4 \mathrm{~m}$ height was especially obvious (Figure $8 \mathrm{~h}$ ). One month later, the wood surface was severely damaged. The comparison of micrographs (Figure 8i-1) indicated that the damage at the $1 \mathrm{~m}$ height was the slightest, while that at the $4 \mathrm{~m}$ height was slightly severe. The variation in the wood surface structure along the axial height was slightly different. 
It is inferred that the bottom material of Chinese fir has better weatherproof performance than the top material.

The correlation between density and weathering behaviour of Cunninghamia lanceolata was found in Table 2 and Figure 8. It was found that the weathering behaviour of Chinese fir was also positively correlated with the wood density; where the density was relatively high, the weatherproofing was strong, and vice versa. It can be concluded that weathering resistance is related to the characteristics of Cunninghamia lanceolata. Improving the basic properties of wood (e.g., density) would have a positive impact on the weatherproof properties. For example, thermo-mechanical densification of wood can improve the dimensional stability and durability of wood [52].

\subsection{Discoloration of Wood Surface}

The colour of the wood is influenced by light radiation, rainwater, and temperature, among other factors. In particular, UV light causes remarkable colour changes. Wood absorbs light and interacts with polymeric compounds and photons. This property leads to deterioration and discolouration when the wood is exposed to natural conditions. The change in wood colour reflects the change in the wood chemical composition during photodegradation. Colour stability is an important wood parameter [36,53-55].

When the samples were exposed to a natural environment for one month, a significant colour change occurred. Figure 9 shows the colour parameters $\left(\mathrm{L}^{*}, \mathrm{a}^{*}, \mathrm{~b}^{*}, \mathrm{c}^{*}\right)$ of heartwood and sapwood surfaces at different heights when the wood was exposed to natural conditions. The lightness value $\left(\mathrm{L}^{*}\right)$ of sapwood was much higher than that of heartwood before exposure. After 6 days of initial exposure, the sapwood lightness decreased significantly, and the value was similar to that of heartwood. The value then tended to be stable, indicating that the trend of continued darkening was weakening. The lightness of heartwood showed a downward trend within 12 days of exposure, and then followed an upward trend (Figure 9a). This shows that the heartwood surface became darker at first and then brightened during exposure for one month. It can be seen from Figure $9 b-d$ that $a^{*}$ (redness), $\mathrm{b}^{*}$ (yellowness), and $\mathrm{c}^{*}$ (chroma) increased significantly during the 6 days exposure. The maximum values were reached after the 6 days of exposure and then began to decrease. One month later, the $a^{*}$ (redness) was lower than that of the unexposed wood; the $b^{*}$ (yellowness) and chroma of sapwood were higher than those of heartwood.

In the weathering process, cellulose has little effect and does not bring obvious discoloration $[45,56,57]$. The yellowing of wood surfaces is due to the modification of hemicellulose and lignin. Lignin is more susceptible to photochemical reactions, resulting in chromogenic groups. Lignin is a good absorbent, and its absorption wavelength can reach $400 \mathrm{~nm}$ with a peak value of $280 \mathrm{~nm}$. Phenolic hydroxyl groups react with light quickly to form phenolic groups, which are converted to $o$ - and $p$-quinonoid structures by demethylation or by cleavage of side chains and formation of carbonyl based chromophoric groups $[40,46,58]$. The generation of chromophoric units brings a huge change in colour. In general, heartwood contains more extractives than sapwood. Therefore, the colour of heartwood was darker than that of sapwood (Figure 9a), with higher $a^{*}$ (redness) (Figure 9b) and lower $c^{*}$ (chroma) (Figure 9d) at the initial stage. 

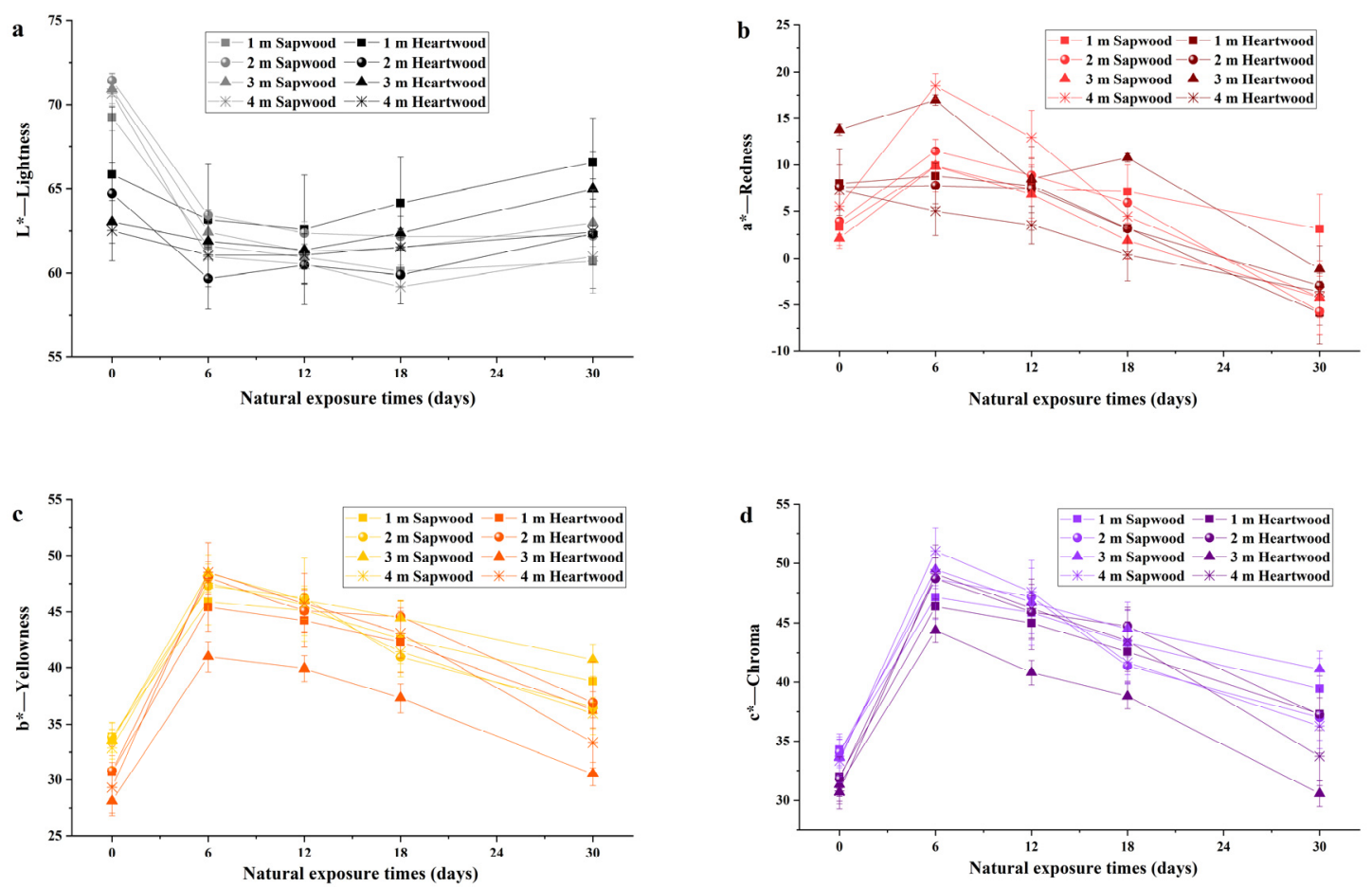

Figure 9. Colour coordinates of Cunninghamia lanceolata due to natural weathering: (a) Lightness L*; (b) redness a*; (c) yellowness b*; (d) chroma c*.

Table 3 summarizes the results of chroma difference $\Delta C^{*}$, total difference $\Delta \mathrm{E}^{*}$, and hue difference $\Delta \mathrm{H}^{*}$ along the radial direction and the axial height. The results show that the colour of $\Delta \mathrm{C}^{*}$ decreased with exposure time. By comparison, it was found that the colour change values in the rectangle on Table 3 showed regularity within 12 days. In the axial direction, the sapwood increased with axial height, and the changes in $\Delta \mathrm{C}^{*}, \Delta \mathrm{E}^{*}$, and $\Delta \mathrm{H}^{*}$ were larger. According to other studies, the density towards the top decreases due to the maturity of the bottom wood tissue. This also explains why the wood quality at the bottom of the logs was superior to that at the top. This phenomenon is consistent with the auxin gradient theory [38]. According to this theory, endogenous auxin produced by growing apical regions promotes the formation of division and xylem differentiation. Therefore, the early wood yield near the canopy is higher, resulting in a lower density of the top wood, a decrease in strength, and an increase in the relative content of lignin. The surface colour of sapwood darkened over the course of the 12 days. In the radial direction, within 12 days, the chroma difference $\Delta C^{*}$ of heartwood changed more than that of sapwood. The chroma value was lower before the exposure of the heartwood in its position. The $\Delta \mathrm{E}^{*}$ value of sapwood was higher than that of heartwood, and the colour change of sapwood was significant in this period because the heartwood contained more extractives, which played a certain role in the resistance to photodegradation in the early stage of weathering. The current research results are consistent with a previous study [59].

Lots of references showed that colour changes were the result of the changes in wood chemistry $[35,45,56,60]$. The results of this article show that, within one month of exposure, the colour change was obvious. This indicates that the decomposition of the chemical components of the wood surface intensified. Colour data can be obtained quickly and conveniently. The influence of weathering on the surface of wood can be rapidly discovered after analysing the data. This means that colour change can be used as a parameter with which to predict the effects of weathering in a short period. After one month of exposure, the initial anatomical structure of the wood surface was basically completely damaged. The colour and structural changes of wood surfaces during the first month of weathering are the most intuitive and accurate. The method used in this study can quickly identify the 
weathering characteristics of wood and can play an active role in the investigation of the effects of wood weatherproofing treatment.

Table 3. Chroma difference $\left(\Delta \mathrm{C}^{*}\right)$, total colour-difference value $\left(\Delta \mathrm{E}^{*}\right)$, and hue difference $\left(\Delta \mathrm{H}^{*}\right)$ are the coordinate-average values and standard deviations (in parentheses) of Chinese fir after natural weathering.

\begin{tabular}{|c|c|c|c|c|c|c|c|}
\hline \multirow{2}{*}{$\begin{array}{l}\text { Exposure } \\
\text { Time (d) }\end{array}$} & \multirow{2}{*}{$\begin{array}{l}\text { Height } \\
\text { (m) }\end{array}$} & \multicolumn{2}{|c|}{$\Delta \mathrm{C}^{*}$} & \multicolumn{2}{|c|}{$\Delta \mathrm{E}^{*}$} & \multicolumn{2}{|c|}{$\Delta \mathbf{H}^{*}$} \\
\hline & & Sapwood & Heartwood & Sapwood & Heartwood & Sapwood & Heartwood \\
\hline \multirow{8}{*}{6} & \multirow{2}{*}{1} & 13.06 & 14.37 & 15.96 & 15.47 & 4.57 & 4.68 \\
\hline & & $(1.83)$ & $(2.91)$ & $(1.71)$ & $(2.44)$ & $(1.60)$ & $(0.26)$ \\
\hline & \multirow{2}{*}{2} & 14.63 & 16.89 & 17.43 & 17.92 & 4.99 & 3.11 \\
\hline & & $(0.27)$ & $(0.56)$ & $(0.21)$ & $(0.47)$ & $(0.61)$ & $(0.95)$ \\
\hline & \multirow{2}{*}{3} & 15.87 & 13.05 & 18.87 & 13.32 & 5.62 & 2.34 \\
\hline & & $(0.34)$ & $(0.12)$ & $(0.55)$ & $(0.09)$ & $(1.00)$ & $(0.41)$ \\
\hline & \multirow{2}{*}{4} & 17.68 & 18.31 & 21.86 & 19.39 & 8.43 & 5.51 \\
\hline & & $(0.50)$ & (1.53) & $(0.34)$ & $(1.74)$ & $(0.34)$ & $(2.97)$ \\
\hline \multirow{8}{*}{12} & \multirow{2}{*}{1} & 11.80 & 13.00 & 14.84 & 14.21 & 2.62 & 3.97 \\
\hline & & $(1.98)$ & $(3.12)$ & $(1.77)$ & $(2.57)$ & $(1.82)$ & $(1.38)$ \\
\hline & \multirow{2}{*}{2} & 13.09 & 14.09 & 16.36 & 15.27 & 2.99 & 2.93 \\
\hline & & $(1.20)$ & (1.17) & $(1.29)$ & (1.29) & $(2.15)$ & $(2.38)$ \\
\hline & \multirow{2}{*}{3} & 13.09 & 9.49 & 16.80 & 13.07 & 3.32 & 8.77 \\
\hline & & $(2.63)$ & $(0.30)$ & $(2.17)$ & $(0.57)$ & $(2.12)$ & $(0.64)$ \\
\hline & \multirow{2}{*}{4} & 14.22 & 15.42 & 18.11 & 17.15 & 4.39 & 6.18 \\
\hline & & $(0.56)$ & (1.15) & $(1.32)$ & (1.12) & (2.07) & $(3.94)$ \\
\hline \multirow{8}{*}{18} & \multirow{2}{*}{1} & 9.29 & 10.59 & 13.74 & 13.20 & 3.48 & 6.54 \\
\hline & & $(3.48)$ & $(3.50)$ & $(3.24)$ & $(3.29)$ & $(1.75)$ & (3.18) \\
\hline & \multirow{2}{*}{2} & 7.33 & 12.93 & 11.88 & 15.26 & 1.04 & 6.41 \\
\hline & & (0.09) & $(0.74)$ & $(0.13)$ & $(0.40)$ & $(0.32)$ & $(0.92)$ \\
\hline & \multirow{2}{*}{3} & 10.92 & 7.50 & 14.50 & 9.67 & 1.31 & 6.06 \\
\hline & & $(0.15)$ & $(0.30)$ & $(0.15)$ & $(0.22)$ & $(0.28)$ & $(0.35)$ \\
\hline & \multirow{2}{*}{4} & 8.34 & 12.70 & 14.35 & 15.46 & 2.21 & 8.42 \\
\hline & & $(0.24)$ & $(1.23)$ & $(0.18)$ & $(0.27)$ & $(0.27)$ & (2.03) \\
\hline \multirow{8}{*}{30} & \multirow{2}{*}{1} & 5.40 & 5.30 & 11.46 & 15.48 & 4.47 & 13.97 \\
\hline & & (3.68) & (1.48) & (3.61) & $(6.54)$ & $(2.44)$ & $(6.88)$ \\
\hline & \multirow{2}{*}{2} & 2.93 & 5.44 & 13.97 & 13.00 & 9.46 & 10.88 \\
\hline & & $(3.31)$ & $(3.01)$ & (1.55) & (2.18) & (1.54) & (2.19) \\
\hline & \multirow{2}{*}{3} & 7.51 & -0.76 & 13.18 & 15.39 & 6.09 & 15.08 \\
\hline & & (1.52) & $(0.36)$ & (1.87) & $(0.63)$ & $(3.80)$ & $(0.48)$ \\
\hline & \multirow{2}{*}{4} & 2.92 & 2.93 & 14.25 & 11.74 & 9.73 & 11.02 \\
\hline & & (1.52) & (1.16) & $(0.31)$ & $(4.48)$ & $(0.85)$ & $(5.06)$ \\
\hline
\end{tabular}

\section{Conclusions}

Changes in the surface of Cunninghamia lanceolata were observed and analysed under natural conditions. The variation in intrinsic weathering behaviour was determined by physical and anatomical research. The colour change of the surface of the wood was evident from the beginning of exposure. The observed structural changes were not detected until one week of exposure. However, the surface microstructure of Chinese fir was seriously damaged after one month of exposure.

The colour change of the surface of Chinese fir was inhibited by extractives at the beginning of exposure. Nevertheless, with the prolongation of exposure time, it was found that the weathering resistance of heartwood was still lower than that of sapwood. Weathering behaviour of Chinese fir was enhanced from bottom to top in the axial direction. This study indicated that the photodegradation of wood decreased with an increase in the density. The high-density timber should be selected to mitigate the effects of weathering on wood.

Understanding the weathering behaviour of wood provides reference for weatherproofing pre-treatment. Obtaining the weathering behaviour of wood can result in a more effective use of wood, 
fully leveraging the advantages of the wood itself and maximally improving the efficiency of wood. Considering the depletion of forest resources, the efficient use of wood also protects the environment.

Author Contributions: Data curation: X.C.; supervision: J.M.; writing-original draft preparation: X.C.; writing-review and editing: J.M. All authors have read and agreed to the published version of the manuscript.

Funding: This research received no external funding.

Conflicts of Interest: The authors declare no conflict of interest.

\section{References}

1. Fu, L.; Yu, Y.; Robert, R.M. Taxodiaceae. Flora China 1999, 4, 54-61.

2. Ken, F. Tropical Plants Database, Tropical.Theferns.Info. Available online: tropical.theferns.info/viewtropical. php?id=Cunninghamia+lanceolata (accessed on 11 December 2020).

3. Jøker, D. Cunninghamia Lanceolata (Lamb.) Hook. SEED LEAFLET, No.43 October 2000. Available online: https://sl.ku.dk/rapporter/seed-leaflets/filer/cunninghamia-lanceolata-43.pdf (accessed on 11 December 2020).

4. Orwa, C.; Mutua, A.; Kindt, R.; Jamnadass, R.; Simons, A. Cunninghamia Lanceolata (Lamb.) Hook. Agroforestry Database 4.0. 2009, pp. 1-5. Available online: http://apps.worldagroforestry.org/treedb2/ AFTPDFS/Cunninghamia_lanceolata.PDF (accessed on 11 December 2020).

5. Minghe, L.; Ritchie, G.A. Eight hundred years of clonal forestry in China: I. traditional afforestation with Chinese fir (Cunninghamia lanceolata (Lamb.) Hook.). New For. 1999, 18, 131-142. [CrossRef]

6. Zhou, W.F.; Huang, Z.X.; Xu, P.; Zhu, J.Z.; Liu, D.L. Determination of Chemical Constituents of the Essential Oil from the Root of Cunninghamia lanceolata. Fine Chem. China 2007, 24, 1095-1098.

7. Xing, J.-Q.; Ikuo, M.; Wakako, O. Natural resistance of two plantation woods Populus $\times$ canadensis cv. and Cunninghamia lanceolata to decay fungi and termites. For. Stud. China 2005, 7, 36-39. [CrossRef]

8. Luo, L.; Wu, Y.; He, X.; Qin, W. Analysis of Building Materials for Wind and Rain Bridge. Materials Science, Energy Technology and Power Engineering III (MEP 2019). In Proceedings of the AIP Conference Proceedings, Hohhot, China, 28-29 July 2019; AIP Publishing: Melville, NY, USA, 2019; Volume 2154, p. 020050. [CrossRef]

9. Cai, L.; Ferretto, P.W.; Deng, Y. A Study of the Timber Structure of Drum Towers of Chinese Dong Minority Architecture and Its Development Evolution. In Proceedings of the 20th IIWC International Conference and Symposium, Falun, Sweden, 13-16 April 2016; pp. 51-61. Available online: http://iiwc.icomos.org/assets/caiferretto-deng-falun.pdf (accessed on 11 December 2020).

10. Hon, N.S.; Feist, W.C. Weathering characteristics of hardwood surfaces. Wood Sci. Technol. 1986, 20, 169-183.

11. Evans, P.D. A note on assessing the deterioration of thin wood veneers during weathering. Wood Fiber Sci. 1988, 20, 487-492.

12. Anderson, E.L.; Pawlak, Z.; Owen, N.L.; Feist, W.C. Infrared studies of wood weathering. Part II: Hardwoods. Appl. Spectrosc. 1991, 45, 648-652. [CrossRef]

13. Nzokou, P.; Kamdem, D.P.; Temiz, A. Effect of accelerated weathering on discoloration and roughness of finished ash wood surfaces in comparison with red oak and hard maple. Prog. Org. Coat. 2011, 71, 350-354. [CrossRef]

14. Agnieszka, J. The study of changes in color of wood angelim pedra (Hymenolobium sp.) and piquia (Caryocar sp.) during artificial weathering. For. Wood Technol. 2013, 82, 339-343.

15. Zborowska, M.; Stachowiak-Wencek, A.; Waliszewska, B.; Prądzyński, W. Comparative studies of ipe (Tabebuia spp.) wood photodegradation cause by treatment with outdoor and indoor UV-A light irradiation. For. Wood Technol. 2014, 88, 292-296.

16. Jankowska, A.; Artur, W.; Mazurek, A. The influence of artificial weathering on changes in color of selected coniferous wood species. For. Wood Technol. 2014, 85, 95-100.

17. Akachuku, A.E. The possibility of tree selection and breeding for genetic improvement of wood properties of Gmelina arborea. For. Sci. 1984, 30, 275-283.

18. Watanabe, U.; Norimoto, M.; Fujita, M.; Gril, J. Transverse shrinkage anisotropy of coniferous wood investigated by the power spectrum analysis. J. Wood Sci. 1998, 44, 9-14. [CrossRef]

19. Ivković, M.; Gapare, W.J.; Abarquez, A.; Ilic, J.; Powell, M.B.; Wu, H.X. Prediction of wood stiffness, strength, and shrinkage in juvenile wood of radiata pine. Wood Sci. Technol. 2009, 43, 237-257. [CrossRef] 
20. Hasegawa, M.; Takata, M.; Matsumura, J.; Oda, K. Effect of wood properties on within-tree variation in ultrasonic wave velocity in softwood. Ultrasonics 2011, 51, 296-302. [CrossRef] [PubMed]

21. Borrega, M.; Gibson, L.J. Mechanics of balsa (Ochroma pyramidale) wood. Mech. Mater. 2015, 84, 75-90. [CrossRef]

22. Williams, R.S. Weathering of wood. In Handbook of Wood Chemistry and Wood Composites, 2nd ed.; Rowell, R.M., Ed.; CRC Press: Boca Raton, FL, USA, 2005; pp. 139-185.

23. Buchner, J.; Irle, M.; Belloncle, C.; Michaud, F.; Macchioni, N. Fungal and bacterial colonies growing on weathered wood surfaces. Wood Mater. Sci. Eng. 2018, 14, 33-41. [CrossRef]

24. Evans, P.D.; Thay, P.D.; Schmalzl, K.J. Degradation of wood surfaces during natural weathering. Effects on lignin and cellulose and on the adhesion of acrylic latex primers. Wood Sci. Technol. 1996, 30, 411-422. [CrossRef]

25. Tolvaj, L.; Németh, R.; Varga, D.; Molnar, S. Colour homogenisation of beech wood by steam treatment. Drewno 2009, 52, 5-17.

26. High Precision with New Designed Sensor and Auto-Weighing Function Electronic Densimeter. Available online: https://www.alfamirage.com/english/catalog/data/300s_features.pdf (accessed on 11 December 2020).

27. Operating Instructions Model H-300S-PCE Instruments. Available online: https://www.pce-instruments. com/english/slot/2/download/5845273/h-300s_gb.pdf (accessed on 11 December 2020).

28. Japan Meteorological Agency. Available online: http://www.jma.go.jp/jma/index.html (accessed on 11 December 2020).

29. Scheffer, T.C. A climate index for estimating potential for decay in wood structures above ground. For. Prod. J. 1971, 21, 25-31.

30. Calculate Wood Decay Hazard Index (Scheffer Index). Available online: https://www.wbdg.org/tools/ corrdefense/wood_decay.html (accessed on 11 December 2020).

31. Kataoka, Y.; Kiguchi, M. Weatherability of water-borne wood preservative semi-transparent coatings(I)-Coating performance during 24 months of natural weathering. Wood Preserv. 2009, 35, $204-214$. [CrossRef]

32. Hatae, F.; Kataoka, Y.; Kiguchi, M.; Matsunaga, H.; Matsumura, J. In site visualization of wood degradation during artificial weathering by variable pressure scanning electron microscopy. In Proceedings of the 11th Pacific Rim Bio-Based Composites Symposium, Shizuoka, Japan, 27-30 November 2012; pp. 226-232.

33. Hatae, F.; Kataoka, Y.; Kiguchi, M.; Matsunaga, H.; Matsumura, J. Use of variable pressure scanning electron microscopy for in situ observation of degradation of wood surfaces during artificial weathering. In Proceedings of the International Research Group on Wood Protection, Kuala Lumpur, Malaysia, 5-6 October 2012.

34. Cao, Y.; Jiang, J.; Lu, J.; Huang, R.; Jiang, J.; Wu, Y. Color change of Chinese fir through steam-heat treatment. Bioresources 2012, 7, 2809-2819.

35. Robertson, A.R. The CIE 1976 color-difference formulae. Color Res. Appl. 1977, 2, 7-11. [CrossRef]

36. Tolvaj, L.; Faix, O. Artificial ageing of wood monitored by DRIFT spectroscopy and CIE L*a* b* color measurements. I. Effect of UV light. Holzforschung 1995, 49, 397-404. [CrossRef]

37. Missanjo, E.; Matsumura, J. Wood Density and Mechanical Properties of Pinus kesiya Royle ex Gordon in Malawi. Forests 2016, 7, 135. [CrossRef]

38. Larson, P.R. Wood Formation and the Concept of Wood Technology; McGraw Hill: New York, NY, USA, 1969; Volume 1.

39. Yin, Y.; Bian, M.; Song, K.; Xiao, F.; Jiang, X. Influence of Microfibril angle on within-tree variations in the Mechanical properties of chinese fir (Cunninghamia Lanceolata). IAWA J. 2011, 32, 431-442. [CrossRef]

40. Ren, H.; Nakai, T. Intratree variability of wood density and main wood mechanical properties in Chinese fir and poplar plantation. Sci. Silvae Sin. 2006, 42, 13-20.

41. Roger, M.R.; Sandra, E.L.; Rodney, E.J. Weathering Performance of Plant-Fiber/Thermoplastic Composites. Mol. Cryst. Liq. Cryst. Sci. Technol. Sect. A Mol. Cryst. Liq. Cryst. 2000, 353, 85-94. [CrossRef]

42. Miniutti, V.P. Microscopic Observations of Ultraviolet Irradiated and Weathered Softwood Surfaces and Clear Coatings; FPL 74; U.S. Department of Agriculture, Forest Service; Forest Products Laboratory: Madison, WI, USA, 1967.

43. Bauch, J.; Berndt, H. Variability of the chemical composition of pit membranes in bordered pits of gymnosperms. Wood Sci. Technol. 1973, 7, 6-9. [CrossRef] 
44. Maschek, D.; Goodell, B.; Jellison, J.; Lessard, M.; Militz, H. A new approach for the study of the chemical composition of bordered pit membranes: 4Pi and confocal laser scanning microscopy. Am. J. Bot. 2013, 100, 1751-1756. [CrossRef]

45. Pandey, K.K. Study of the effect of photo-irradiation on the surface chemistry of wood. Polym. Degrad. Stab. 2005, 90, 9-20. [CrossRef]

46. Rowell, R.M.; Roger, P.; James, S.H.; Jeffrey, S.R.; Mandla, A.T. Cell wall chemistry. In Handbook of Wood Chemistry and Wood Composites, 2nd ed.; Rowell, R.M., Ed.; CRC Press: Boca Raton, FL, USA, 2005; pp. 35-74.

47. William, C.F.; David, N.S.H. Chemistry of weathering and protection. In The Chemistry of Solid Wood, Advances in Chemistry Series 207; Rowell, R.M., Ed.; American Chemical Society: Washington, DC, USA, 1984; pp. 401-451.

48. Kollmann, F.F.P.; Kuenzi, E.W.; Stamm, A.J. Principles of Wood Science and Technology: II Wood Based Materials; Springer-Verlag: Heidelberg/Berlin, Germany, 1975.

49. Shmulsky, R.; Jones, P.D. Forest Products and Wood Science: An Introduction; WILEY Blackwell: Hoboken, NJ, USA, 2019.

50. Nicholas, D.D. Wood Deterioration and Its Prevention by Preservative Treatments: Volume 1: Degradation and Protection of Wood; Syracuse University Press: New York, NY, USA, 1982; ISBN 0815622856.

51. Li, Y.F.; Deng, X.W.; Zhang, Y.F.; Huang, Y.Q.; Wang, C.Y.; Xiang, W.H.; Xiao, F.M.; Wei, X.C. Chemical Characteristics of Heartwood and Sapwood of Red-Heart Chinese Fir (Cunninghamia lanceolata). For. Prod. J. 2019, 69, 103-109. [CrossRef]

52. Welzbacher, C.R.; Wehsener, J.; Rapp, A.O.; Haller, P. Thermo-mechanical densification combined with thermal modification of Norway spruce (Picea abies Karst) in industrial scale-Dimensional stability and durability aspects. Holz als Roh-und Werkstoff 2008, 66, 39-49. [CrossRef]

53. Mitsui, K.; Tsuchikawa, S. Low atmospheric temperature dependence on photodegradation of wood. J. Photochem. Photobiol. B Biol. 2005, 81, 84-88. [CrossRef] [PubMed]

54. Miklečić, J.; Jirous-Rajkovic, V.; Antonović, A.; Španić, N. Discolouration of thermally modified wood during simulated indoor sunlight exposure. Bioresources 2011, 6, 434-446. [CrossRef]

55. Rüther, P.; Jelle, B.P. Color changes of wood and wood-based materials due to natural and artificial weathering. Wood Mater. Sci. Eng. 2013, 8, 13-25. [CrossRef]

56. Calienno, L.; Lo Monaco, A.; Pelosi, C.; Picchio, R. Colour and chemical changes on photodegraded beech wood with or without red heartwood. Wood Sci. Technol. 2014, 48, 1167-1180. [CrossRef]

57. Wang, X.Q.; Fei, B.H.; Ren, H.Q. FTIR spectroscopic studies of the photo-discoloration of Chinese fir. Spectrosc. Spectr. Anal. 2009, 29, 1272-1275.

58. Hon, D.N.S. Photochemistry of wood. In Wood and Cellulosic Chemistry; Hon, D.N.S., Shiraishi, N., Eds.; Marcel Decker lic: New York, NY, USA, 1991; pp. 525-555. ISBN 9780824700249.

59. Chang, T.-C.; Chang, H.-T.; Wu, C.-L.; Chang, S.-T. Influences of extractives on the photodegradation of wood. Polym. Degrad. Stab. 2010, 95, 516-521. [CrossRef]

60. Kržišnik, D.; Lesar, B.; Thaler, N.; Humar, M. Influence of Natural and Artificial Weathering on the Colour Change of Different Wood and Wood-Based Materials. Forests 2018, 9, 488. [CrossRef]

Publisher's Note: MDPI stays neutral with regard to jurisdictional claims in published maps and institutional affiliations.

(C) 2020 by the authors. Licensee MDPI, Basel, Switzerland. This article is an open access article distributed under the terms and conditions of the Creative Commons Attribution (CC BY) license (http://creativecommons.org/licenses/by/4.0/). 